\title{
Role of Age and Experience in Attacking Tactical Knowledge among Iranian Soccer School Players
}

\author{
Influencia de la edad y la experiencia sobre el conocimiento táctico en ataque de \\ jugadores de fútbol iraníes en edad escolar
}

\author{
Jaime Serra Olivares ${ }^{1}$, Mohammad Maleki ${ }^{2}$, Arash Zarei ${ }^{2}$ \\ 1 Facultad de Educación. Universidad Católica de Temuco, Chile. \\ 2 University of Kurdistan, Sanandaj, Irán.
}

CORRESPONDENCIA:

Mohammad Maleki.

mo.maleki@uok.ac.ir

Recepción. mayo 2020 • Aceptación: abril 2021
CÓMO CITAR EL ARTÍCULO:

Serra, J., Maleki, M., \& Zarei, A. (2021). Role of Age and Experience in Attacking Tactical Knowledge among Soccer School Players. Cultura, Ciencia y Deporte, 16(49), 485-496. http://dx. doi.org/10.12800/ccd.v16i49.1453

\begin{abstract}
This study was conducted to evaluate and compare declarative and procedural knowledge among the Iranian soccer schools' players with different age and level of experience. Totally, 456 soccer schools' players with $\mathrm{U}-10, \mathrm{U}-13$ and $\mathrm{U}-16$ age groups and three categories of high, middle, and low experience of competition were included in this study and completed the Soccers' Tactical Knowledge Test. Participants responded to a written multiple-choice test on theoretical information and rules and representative figures of a game situation for evaluation of declarative and procedural tactical knowledge, respectively. Results showed significant differences in total, declarative, and procedural tactical knowledge among different age and level of experience groups. Results of the Bonferroni post-hoc test revealed significant differences only between $\mathrm{U}-16$ and $\mathrm{U}-13$ with U-10 groups, and between high and middle with low level of experience groups $(p=0.00)$. In the sub-scales of the declarative and procedural tactical knowledge, U-16 and high-experienced players performed better than $\mathrm{U}-10$ and low-experienced ones $(p=0.00)$. Furthermore, significant differences observed between $U-16$ and $U-10$ players in declarative and procedural tactical knowledge $(p=0.00)$ confirmmed that not only length of time to explore sport-specific concepts, but also psycho-physical development of children/adolescents influenced acquisition of tactical knowledge in invasion team sports like soccer possibly due to soccers' competitive experience. Our findings suggested that improvement of declarative and procedural tactical knowledge in the initial years influences the individuals' future success in soccer.
\end{abstract}

Key words: Physical education, soccer school, evaluation, maturation, adolescents, tactical knowledge

\section{Resumen}

Se evaluó y comparó el conocimiento declarativo y procedimental de jugadores de fútbol iraníes en edad escolar, con diferentes niveles de edad y experiencia. Un total de 456 jugadores de categorías Sub-10, Sub-13 y Sub 16 organizados en grupos de experiencia en competición (alta, media y baja) completaron el Test de Conocimiento Táctico Ofensivo en Fútbol (TCTOF). Los resultados muestran diferencias significativas en el conocimiento táctico, declarativo y procedimental en función de los diferentes grupos de nivel, edad y experiencia. Los hallazgos del test post-hoc de Bonferroni revelan diferencias significativas entre los grupos de experiencia (Sub-16, Sub-13 y Sub-10) y entre los grupos de nivel alto y medio con el grupo de nivel bajo de experiancia $(p=0.00)$. El grupo Sub-16 y con experiencia alta obtuvo resultados significativamente superiores en el test que el grupo U-10 y con baja experiencia $(p=0.00)$.

Además, se observaron diferencias significativas entre lo grupos Sub-16 y Sub-10 en las partes del test declarativa y procedimental $(p=0.00)$. Los resultados confirman la influencia de la experiencia en competición (exposición a conceptos deportivos específicos y del desarrollo psicofísico) sobre el nivel de conocimiento táctico sobre los deportes de invasión como el fútbol. Se sugiere que la mejora del conocimiento táctico declarativo y procedimental en las primeras edades influiría sobre el nivel de rendimiento en fútbol en test similares.

Palabras clave: educación física, fútbol, evaluación, maduración, adolestentes, conocimiento táctico. 


\section{Introduction}

Invasion games' beginners face different tactical problems regarding attack and defense restricting their game behaviors (Bayer, 1992). Since, athletes' decisions depend on structure of prior knowledge, the ability to process new information and the interaction between individual, task, and context constraints (Domínguez La Rosa \& Espeso, 2002; Starkes \& Ericsson, 2003), study on the learners' prior knowledge and its relationship with the ability of playing has been widely emphasized (De la Vega et al., 2008; García-González et al., 2011; Griffin et al., 2001). Tactical knowledge is dependent on strong relationships between action rules, game organization, and motor capacities related to knowledge and game performance (Gréhaigne, 1992). In this sense, increasing the game sense and player's capability to understand the games' situations is crucial for improvement of performance (Grehaigne et al., 2005). Given uncertain and unpredictable environment, proper decision- making during the invasion games requires having good tactical knowledge (Suppiah et al., 2015). Thus, development of tactical knowledge (Williams \& Davids, 1995) is one of essential cognitive components of decision-making in high-performance athletes facilitating the access to sport-specific information of working memory (Williams et al., 2012).

In the sports with unpredictable environment like soccer, declarative tactical knowledge is related to the acquired basic and theoretical information by learners. A relationship will be established between aspects related to why and how processes and applying the concepts when making a good decision during the real games' situations through practice and achieving experience that refers to procedural tactical knowledge (Griffin, et al., 2001). It has been shown that a combination of a good declarative (knowing what to do) and procedural (knowing how to do) tactical knowledge as well as experience plays an important role in articulation and function of other cognitive processes during playing games (Blomqvist \& Vänttinen, 2006). These assumptions highlight importance of development of qualitative evaluation process of tactical knowledge in the athletes in order to build constructive teaching-learning process, with respect to their needs (Webb \& Pearson, 2008). Accordingly, evaluation of learners' tactical knowledge in the early ages, through methods like questioning will be high useful in teaching invasion games (Costa \& Reyes, 2015; Serra-Olivares \& García-López, 2016). In the same way, tactical knowledge, as the ability to use motor concepts, principles, strategies, and tactics will be improved by practice leading to articulation of the athlete's understanding about game (Mitchell et al., 2013). Understanding the game is the ability to solve tactical problems by choosing appropriate solutions in different situations as well as justifying the choice properly (Blomqvist et al., 2000). Therefore, successful performance in invasion games is not only the result of appropriate technical and tactical actions, but also depends on the athlete's tactical knowledge and understanding of the games' situation (Dicks et al., 2008). Tactical knowledge, as a necessary cognitive feature and capability plays an important role in adaptation to game context for players. Then, the more tactical knowledge the player has, the better understanding of game and its rules and tactics he/she will has (González-Víllora et al., 2015). Thus, recently, great effort has been devoted to evaluate tactical knowledge in invasion games like soccer (Blomqvist et al., 2005; Elferink-Gemser et al., 2004; García-López et al., 2010; Giacomini et al., 2011; González-Víllora et al., 2010; González-Víllora et al., 2011).

Moreno et al. (2008) studied tactical knowledge of senior, U-19, and U-14 female volleyball setters through video sequences and interview tests and found that the players with higher levels of practice provided more complex and structured action plan and the current event profiles, attributed to an increase in cognitive biological growth-induced capacity and experiences gained during sport practice sessions (Matias \& Greco, 2010). García-López et al. (2010) compared procedural tactical knowledge among 140 U-16 soccer players from international, national, regional, provincial, and low-experienced categories based on conceptualization of tactical knowledge in terms of generalized stimulus-response pairs (Anderson, 1982). The players were asked to respond to a video-based test consisting of seven sequences of four U-16 Spanish soccer play-off games. These sequences supposed to represent stimulus-response pairs were selected based on the role of players (defense and attack) with and without ball (defense, midfield ,and forward), as well as tactical principles of attack and defense (Bayer, 1992). The results showed that tactical knowledge of national and international players was higher than the other participants. Regarding studying the influence of level of practice on procedural and declarative knowledge of volleyball players with different ages, Gil et al. (2012) in a research asked 535 players aged between $12-16$ years old in the Spanish volleyball championship league to complete two questionnaires of multiple-choice questions adapted from (McGee \& Farrow, 1987). Declarative knowledge questionnaire was related to techniques, terminology, regulations, general 
knowledge and strategy, and procedural knowledge questionnaire was also related to the player's tactical behavior in different situations of volleyball games. It was found that declarative and procedural knowledge was increased by increasing level of practice and age. In addition, when level of practice was considered the same, no difference was found between declarative and procedural knowledge of the individuals with consecutive ages, but a significant difference was found when their level of practice varied. Reviewing the previous works showed that evaluation of declarative (Giacomini et al., 2011; Moreira et al., 2014; Moreno et al., 2008; Serra-Olivares et al., 2015) or procedural tactical knowledge through observational approach (Borges et al., 2017) or video-sequences one (GarcíaLópez et al., 2010) or both of tactical knowledge (Gil et al., 2012) has been considered as an important issue in the field of studying cognitive features of the learners.

Given that both motor and technical skills are based on declarative and procedural knowledge (McPherson \& Kernodle, 2003), attention should be paid to differentiation between on-the-ball and offthe-ball situations (Oslin et al., 1998) during attack or defense (Bjurwill, 1993) in invasion games to sort tactical skill elements related to match. Serra-Olivares \& García-López (2016) developed the Soccer Tactical Knowledge Test (STKT), as an assessment tool to evaluate declarative and procedural tactical knowledge for invasion games. The test analyzes knowledge of the player based on attacking and defense contextual problems at on-the-ball and off-the-ball situations. Recently, García-Ceberino et al. (2020) investigated the effect of two tactical and technical interventions on declarative and procedural tactical knowledge of soccer schools' players aged between 10-11 years old with different gender and level of experience. Evaluation of tactical knowledge through STKT showed that both of interventions led to improvement of tactical knowledge of all the participants. In a previous study by Serra-Olivares et al. (2015), tactical knowledge of 109 soccer players aged between 8-12 years old was evaluated with respect to their age, experience, and expertise through STKT. A significant relationship was found between age, experience, and expertise of the participants with their declarative and procedural knowledge. Americo et al. (2017) in another study compared declarative tactical knowledge of $36 \mathrm{U}-11$ and U-15 soccer players with different levels of experience by recording their practice history and declarative tactical knowledge using questionnaires and verbal responses during video simulation test, respectively. A significant difference was found between declarative tactical knowledge of the two groups. Altogether, evidence suggests that level of practice and experience has a greater role in development of sport-specific knowledge than changes in age (Baker et al., 2003).

In line with growing interest in taking into account declarative and procedural knowledge in education of invasion games, considerable attention has been also paid to evaluation of tactical as well as technical aspects of instruction of the Iranian soccer players (Vazinitaher et al., 2011). In this direction, besides technical and attitude objectives, achievement of cognitive and knowledge objectives has been followed by sport education programs in the Iranian schools and sport clubs. Nevertheless, Salehi Omran et al. (2015) showed that the achieved objectives were mostly skill and attitude ones and mean scores of tactical and sport knowledge objectives were lower than skill and attitude ones in the Iranian students aged between 10-11 years old. Although, a great emphasis has been devoted to learning and evaluating tactics in sport education program in Iran, but Doostdari et al. (2015) found that index of individual-technical skills is still the most important index in talent identification and development in the soccer schools and clubs. Over the last years, sport education programs in Iran have made the players to raise their technics and interests but paying less attention to their knowledge. It is believed that, it might be due to inadequate evaluation of tactical content and knowledge as well as their application within context of real game in training methods. Then, it appears that the process of evaluation of sport knowledge needs to be further considered in Iran. In this regard, in the present study, for testing the hypothesis whether there is a difference between declarative and procedural tactical knowledge of the children and adolescents with different age and level of experience, in on- and off- the-ball situations, soccer players of the Iranian soccer schools aged between 7-16 years old were investigated based on their age and experience by STKT as one of valid instruments for evaluation of tactical knowledge in on- and off- the-ball situations.

\section{Method}

\section{Participants}

Totally, 456 participants from three age groups including $95 \mathrm{U}-10$ players ( $\mathrm{M}=8.5, \mathrm{SD}=0.63$ age), $225 \mathrm{U}-13$ players ( $\mathrm{M}=11.7, \mathrm{SD}=1.03$ age) , and 136 U-16 players ( $\mathrm{M}=15.5, \mathrm{SD}=0.7$ age) from Kurdistan Province soccer schools completed STKT (SerraOlivares \& García-López, 2016). Also, the mentioned participants were categorized into three groups based on their experience of competition including 220 less 
(less than 2 years' competition; $\mathrm{M}=1.5, \mathrm{SD}=0.49$ ), 150 middle (3-4 years competition; $M=3.5, S D=0.5$ ), and 96 high-experienced (5-7 years competition; $\mathrm{M}=5.8, \mathrm{SD}=0.8$ ) players, regardless of their age. Ten participants were excluded from the latter category because they did not state their experience level.

\section{Instruments}

Questionnaire. Since tactical principles of attack (maintaining the possession of the ball, advancing and attacking the goal) and defence (winning the ball, preventing advancing and defending the goal) (Bayer, 1992) consist of tactical problems resulting from the interaction between perceptual capacities, decisionmaking ,and technical and tactical performance in soccer, from an ecological viewpoint, STKT seeks to evaluate the prior knowledge of soccer players in relation to these tactical principles at soccer attack phase. According to this view, for decision-making in sport adaptively, the potential relationships between declarative and procedural knowledge networks should be evaluated. Accordingly, this questionnaire, in addition to measuring individual and group tactical knowledge in soccer as a key element in teaching invasion sports, also measures specific knowledge about soccer regulations and positions as the basic level of soccer's declarative knowledge.
The tool was divided into two separate parts; each part was completed within 15 minutes by the participants. In the first part, 6 indicators of declarative tactical knowledge were evaluated by 36 multiplechoice questions (For example, what is a pass for?). These indicators included techniques, terminology, regulations, general knowledge, and individual and collective strategies when attacking in group sports, especially soccer. The second part assessed 4 indicators of procedural tactical knowledge through 16 multiplechoice questions with figures and followed the scheme of "If..., then..." (McPherson \& Thomas, 1989). These questions were about representation of tactical decision-making of the soccer player in various with and without ball situations (Table 1, Figure 2).

For validating quality of research instrument, first, back-translation method was used. After translation of the English version of questionnaire to Persian, two translators (one of whom was a soccer coach) were asked to translate it to English. Comparing between backtranslated and original English versions, they reached an agreement on terms and concepts. Afterwards, face validity of the translated questionnaire was confirmed by some experts in the field of sport sciences and soccer coaches. Finally, for evaluating reliability of the Persian version of the instrument, Cronbachs' $\alpha$ was measured as 0.86 and 0.76 for declarative and procedural tactical knowledge, respectively.

Table 1. Variables, dimensions, and indicators assessed by STKT.

\section{VARIABLE: TACTICAL KNOWLEDGE IN SOCCER}

\begin{tabular}{|c|c|}
\hline \multicolumn{2}{|c|}{ First Dimension: declarative knowledge related to the attacking phase in soccer } \\
\hline Indicators & Item/s \\
\hline $\begin{array}{l}\text { Domain declarative specific knowledge on the technical and tactical } \\
\text { individual elements in the sport of soccer related to TP when attacking for invasion } \\
\text { games and sports. }\end{array}$ & 1 to 7 \\
\hline Domain declarative specific knowledge on the offside rule in soccer A-7 & 8 \\
\hline Domain declarative specific knowledge on roles and positions in soccer & 9 to 13 \\
\hline $\begin{array}{l}\text { Domain declarative specific knowledge on technical-tactical individual } \\
\text { elements in soccer }\end{array}$ & 14 to 24 \\
\hline $\begin{array}{l}\text { Domain declarative specific knowledge on technical-tactical collective } \\
\text { elements in soccer }\end{array}$ & 25 to 27 \\
\hline $\begin{array}{l}\text { Domain declarative specific knowledge on TP when attacking in invasion } \\
\text { games and sports }\end{array}$ & 28 to 36 \\
\hline \multicolumn{2}{|c|}{ Second Dimension: procedural knowledge related to the attacking phase in soccer } \\
\hline Indicators & Item/s \\
\hline $\begin{array}{l}\text { Domain procedural specific knowledge on the use of individual technical } \\
\text { and tactical elements in situations of keeping the ball in soccer }\end{array}$ & $\begin{array}{l}3,5,6,9 \\
11 \text { and } 13\end{array}$ \\
\hline $\begin{array}{l}\text { Domain procedural specific knowledge on the use of individual technical } \\
\text { and tactical elements in situations of moving forward to the opposite goal in soccer }\end{array}$ & $\begin{array}{l}1,4,7,10, \\
12,14,15\end{array}$ \\
\hline $\begin{array}{l}\text { Domain procedural specific knowledge on the use of individual technical } \\
\text { and tactical elements in situations of scoring in soccer }\end{array}$ & 2 and 8 \\
\hline Domain procedural specific knowledge on the offside rule in soccer A-7 & 16 \\
\hline
\end{tabular}




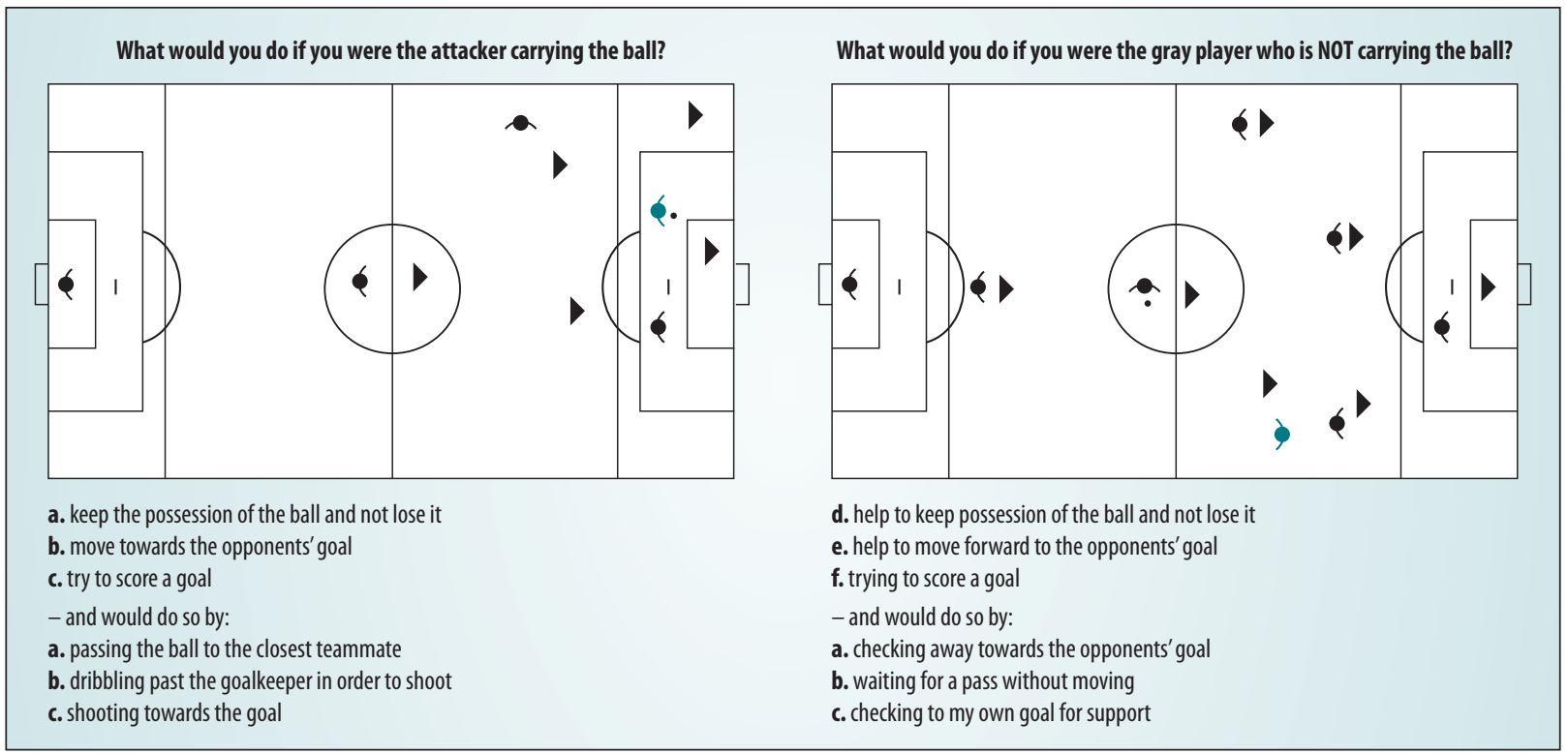

Figure 1. Sample of questions of STKT for assessing procedural tactical knowledge in on- and off- the- ball situations.

\section{Variables}

Two variables were considered as independent ones: 1) Experience including 3 levels of low (less than 2 years), middle (3-4 years), and high (5-7 years) competition experience and 2) age consisting of $\mathrm{U}-10$, U-13 and U-16 age groups. Dependent variables also included levels of attacking declarative and procedural tactical knowledge acquired by the players after completion of questionnaire.

\section{Procedure}

Before starting the study, Kurdistan Province soccer schools' managers and coaches were contacted to explain the study objectives and ask them for voluntary participation. This was done due to two reasons: 1 ) informing them about length of time to respond to the questionnaires (about 30 minutes) occupying time of the practice session; and 2) obtaining permission from the participants' parents and signing the consent form by them.

After obtaining the mentioned permissions, second and third authors attended at soccer schools. Cooperating with respective coaches, the players were sorted into U-10, U-13, and U-16 age groups. Then, the manner of responding to questions was described, proportional to the feedback received from players of different age groups. Before collecting data, an expert explained the research procedure to the participants and was present until the end of the session to answer the questions of the participants, especially for U-10 and U-13 age groups. Players were invited to dressing room of the team as 5-member groups randomly in order to minimize mutual influence on responses. The dressing room was prepared regarding air condition and light by authors. After that, they were asked to complete the questionnaire, under supervision of an author and a coach. First, declarative tactical knowledge and then, procedural knowledge questionnaires were completed, both within 15 minutes. All the questionnaires were completed in even days at 9-11 am.

\section{Analysis}

A 3 (age groups) $\times 3$ (level of experience) design by analysis of variance (ANOVA) was used to analyze declarative and procedural tactical knowledge scales separately. Post-hoc Bonferroni paired comparisons were performed to find significant differences between groups.

\section{Results}

Descriptive analysis showed differences between STKT' indices of soccer players with different age and experience categories (Table 2).

\section{Influence of age}

Results showed significant differences in total, declarative ,and procedural tactical knowledge $\left(\mathrm{F}_{(2,453)}=\right.$ 16.54, Partial $\eta^{2}=0.13 ; \mathrm{F}_{(2,453)}=15.22$, Partial $\eta^{2}=0.12$ and $\mathrm{F}_{(2,453)}=9.57$, Partial $\eta^{2}=0.09 ; \mathrm{p}=0.000$ all $)$ among U-10, U-13 and U-16 groups. Results of Bonferroni post- 
Table 2. Descriptive analysis of variables, dimensions and indicators to assess by STKT in three age and experience categories.

\begin{tabular}{|c|c|c|c|c|c|c|c|c|c|c|}
\hline & $\begin{array}{c}\text { Age } \\
\text { Category }\end{array}$ & $\mathrm{N}$ & Mean & $\begin{array}{c}\text { St. } \\
\text { Deviation }\end{array}$ & $\begin{array}{l}\text { St. } \\
\text { Error }\end{array}$ & $\begin{array}{c}\text { Experience } \\
\text { Category }\end{array}$ & $\mathbf{N}$ & Mean & $\begin{array}{c}\text { St. } \\
\text { Deviation }\end{array}$ & $\begin{array}{c}\text { St. } \\
\text { Error }\end{array}$ \\
\hline \multirow{4}{*}{$\begin{array}{l}\text { Declarative } \\
\text { Knowledge }\end{array}$} & U-10 & 95 & 59.53 & 14.75 & 1.51 & Less & 220 & 63.48 & 15.25 & 1.02 \\
\hline & U-13 & 225 & 68.61 & 15.76 & 1.05 & Middle & 150 & 68.85 & 15.42 & 1.23 \\
\hline & U-16 & 136 & 69.93 & 14.6 & 1.25 & High & 96 & 71.52 & 15.8 & 1.61 \\
\hline & Total & 456 & 67.11 & 15.68 & 0.73 & Total & 466 & 66.9 & 15.74 & 0.73 \\
\hline \multirow{4}{*}{$\begin{array}{l}\text { Tec.-tac. } \\
\text { Individual...1 }\end{array}$} & U-10 & 95 & 81.8 & 15.93 & 1.63 & Less & 220 & 86.04 & 14.21 & 0.96 \\
\hline & U-13 & 225 & 88.88 & 11.32 & 0.75 & Middle & 150 & 87.04 & 14.07 & 1.15 \\
\hline & U-16 & 136 & 89.9 & 13.81 & 1.18 & High & 96 & 92.26 & 10.13 & 1.03 \\
\hline & Total & 456 & 87.71 & 13.47 & 0.63 & Total & 466 & 87.64 & 13.61 & 0.63 \\
\hline \multirow[t]{4}{*}{ Roles\&posi.2 } & U-10 & 95 & 66.14 & 21.81 & 2.23 & Less & 220 & 69.77 & 24.3 & 1.64 \\
\hline & U-13 & 225 & 72.22 & 24.1 & 1.61 & Middle & 150 & 73.9 & 22.13 & 1.81 \\
\hline & U-16 & 136 & 79.41 & 20.61 & 1.77 & High & 96 & 78.3 & 21.91 & 2.23 \\
\hline & Total & 456 & 73.1 & 23.07 & 1.08 & Total & 466 & 72.85 & 23.32 & 1.08 \\
\hline \multirow{4}{*}{$\begin{array}{l}\text { Tech.- tac. } \\
\text { Individual...3 }\end{array}$} & U-10 & 95 & 55.7 & 21.06 & 2.16 & Less & 220 & 59.1 & 20 & 1.35 \\
\hline & U-13 & 225 & 64.81 & 21.43 & 1.42 & Middle & 150 & 65.87 & 21.3 & 1.73 \\
\hline & U-16 & 136 & 66.91 & 19.66 & 1.68 & High & 96 & 68.2 & 22.96 & 2.34 \\
\hline & Total & 456 & 63.53 & 21.2 & 0.99 & Total & 466 & 63.14 & 21.37 & 0.99 \\
\hline \multirow{4}{*}{$\begin{array}{l}\text { Tech.- tac. } \\
\text { Collective...4 }\end{array}$} & U-10 & 95 & 37.9 & 30.21 & 3.1 & Less & 220 & 41.97 & 30.57 & 2.06 \\
\hline & U-13 & 225 & 50.52 & 31.03 & 2.07 & Middle & 150 & 52.44 & 30.24 & 2.47 \\
\hline & U-16 & 136 & 51.47 & 30.05 & 2.58 & High & 96 & 54.51 & 30.25 & 3.09 \\
\hline & Total & 456 & 48.17 & 30.96 & 1.45 & Total & 466 & 47.92 & 30.86 & 1.42 \\
\hline \multirow{4}{*}{$\begin{array}{l}\text { TP when } \\
\text { attacking...5 }\end{array}$} & U-10 & 95 & 49.12 & 22.5 & 2.3 & Less & 220 & 53.53 & 21.46 & 1.44 \\
\hline & U-13 & 225 & 60.74 & 21.36 & 1.42 & Middle & 150 & 60.44 & 20.53 & 1.67 \\
\hline & U-16 & 136 & 57.84 & 20.8 & 1.78 & High & 96 & 60.74 & 23.02 & 2.34 \\
\hline & Total & 456 & 57.45 & 21.84 & 1.02 & Total & 466 & 57.24 & 21.74 & 1 \\
\hline \multirow{4}{*}{$\begin{array}{l}\text { Procedural } \\
\text { Knowledge }\end{array}$} & U-10 & 95 & 17.17 & 11.74 & 1.2 & Less & 220 & 19.77 & 13.9 & 0.93 \\
\hline & U-13 & 225 & 23.6 & 15.2 & 1.01 & Middle & 150 & 24.66 & 15.66 & 1.27 \\
\hline & U-16 & 136 & 25.7 & 16.45 & 1.41 & High & 96 & 26.62 & 15.9 & 1.62 \\
\hline & Total & 456 & 22.87 & 15.23 & 0.71 & Total & 466 & 22.76 & 15.15 & 0.7 \\
\hline \multirow{4}{*}{$\begin{array}{l}\text { Keeping the } \\
\text { ball...6 }\end{array}$} & U-10 & 95 & 15.61 & 18 & 1.84 & Less & 220 & 18.48 & 19.74 & 1.33 \\
\hline & $\mathrm{U}-13$ & 225 & 24.37 & 23.35 & 1.55 & Middle & 150 & 25.88 & 24.54 & 2 \\
\hline & U-16 & 136 & 25.61 & 24.6 & 2.11 & High & 96 & 27.95 & 25.19 & 2.57 \\
\hline & Total & 456 & 22.91 & 23 & 1.07 & Total & 466 & 22.81 & 22.88 & 1.06 \\
\hline \multirow{4}{*}{$\begin{array}{l}\text { Moving } \\
\text { forward...7 }\end{array}$} & U-10 & 95 & 15.63 & 13.67 & 1.4 & Less & 220 & 17.6 & 16.75 & 1.13 \\
\hline & U-13 & 225 & 20.12 & 17.2 & 1.14 & Middle & 150 & 20.76 & 16.76 & 1.36 \\
\hline & U-16 & 136 & 22.16 & 18.95 & 1.62 & High & 96 & 22.61 & 18.61 & 1.9 \\
\hline & Total & 456 & 19.8 & 17.2 & 0.8 & Total & 466 & 19.65 & 17.24 & 0.8 \\
\hline \multirow[t]{4}{*}{ Scoring...8 } & $\mathrm{U}-10$ & 95 & 35.8 & 39.72 & 4.07 & Less & 220 & 41.14 & 38.24 & 2.58 \\
\hline & U-13 & 225 & 45.11 & 38.36 & 2.55 & Middle & 150 & 47 & 38.96 & 3.18 \\
\hline & U-16 & 136 & 51.1 & 37.74 & 3.23 & High & 96 & 50 & 39.07 & 3.99 \\
\hline & Total & 456 & 44.96 & 38.75 & 1.81 & Total & 466 & 44.85 & 38.73 & 1.8 \\
\hline \multirow[t]{4}{*}{ Total TK9 } & U-10 & 95 & 38.35 & 10.84 & 1.11 & Less & 220 & 41.63 & 12.42 & 0.83 \\
\hline & U-13 & 225 & 46.1 & 13.44 & 0.89 & Middle & 150 & 46.76 & 13.6 & 1.11 \\
\hline & U-16 & 136 & 47.81 & 13.45 & 1.15 & High & 96 & 49.07 & 13.52 & 1.38 \\
\hline & Total & 456 & 45 & 13.38 & 0.62 & Total & 466 & 44.81 & 13.38 & 0.62 \\
\hline
\end{tabular}


Table 3. Pair comparisons of age and experience categories in terms of the declarative and procedural tactical knowledge and respected subscales.

\begin{tabular}{|c|c|c|c|c|c|c|}
\hline & Age Category & Mean Differences & $\mathrm{p}$ & Level of Experience & Mean Differences & $\mathrm{p}$ \\
\hline \multirow{3}{*}{$\begin{array}{l}\text { Declarative } \\
\text { Knowledge }\end{array}$} & U-10 vs. U-13 & -13.1 & 0.00 & Less vs. Middle & -5.36 & 0.00 \\
\hline & U-10 vs. U-16 & -12.52 & 0.00 & Less vs. High & -8.04 & 0.00 \\
\hline & U-16 vs. U-13 & -0.58 & 0.73 & High vs. Middle & 2.67 & 0.55 \\
\hline \multirow{3}{*}{$\begin{array}{l}\text { Tec.-tac. } \\
\text { Individual...1 }\end{array}$} & U-10 vs. U-13 & -7.11 & 0.00 & Less vs. Middle & -4.89 & 0.00 \\
\hline & U-10 vs. U-16 & -8.11 & 0.00 & Less vs. High & -6.85 & 0.00 \\
\hline & U-16 vs. U-13 & 0.99 & 1 & High vs. Middle & 1.96 & 0.94 \\
\hline \multirow[t]{3}{*}{ Roles\&posi.2 } & U-10 vs. U-13 & -6.13 & 0.07 & Less vs. Middle & -4.11 & 0.28 \\
\hline & U-10 vs. U-16 & -13.27 & 0.00 & Less vs. High & -8.52 & 0.00 \\
\hline & U-16 vs. U-13 & 7.14 & 0.01 & High vs. Middle & 4.41 & 0.43 \\
\hline \multirow{3}{*}{$\begin{array}{l}\text { Tech.- tac. } \\
\text { Individual...3 }\end{array}$} & U-10 vs. U-13 & -9.16 & 0.00 & Less vs. Middle & -6.78 & 0.00 \\
\hline & U-10 vs. U-16 & -11.21 & 0.00 & Less vs. High & -9.09 & 0.00 \\
\hline & U-16 vs. U-13 & 2.05 & 1 & High vs. Middle & 2.3 & 1 \\
\hline \multirow{3}{*}{$\begin{array}{l}\text { Tech.- tac. } \\
\text { Collective...4 }\end{array}$} & U-10 vs. U-13 & -12.47 & 0.00 & Less vs. Middle & -10.47 & 0.00 \\
\hline & U-10 vs. U-16 & -13.57 & 0.00 & Less vs. High & -12.54 & 0.00 \\
\hline & U-16 vs. U-13 & 1.09 & 1 & High vs. Middle & 2.07 & 1 \\
\hline \multirow{3}{*}{$\begin{array}{l}\text { TP when } \\
\text { attacking...5 }\end{array}$} & U-10 vs. U-13 & -11.71 & 0.00 & Less vs. Middle & -6.91 & 0.00 \\
\hline & U-10 vs. U-16 & -8.72 & 0.00 & Less vs. High & -7.22 & 0.01 \\
\hline & U-16 vs. U-13 & -2.99 & 0.57 & High vs. Middle & 0.32 & 1 \\
\hline \multirow{3}{*}{$\begin{array}{l}\text { Procedural } \\
\text { Knowledge }\end{array}$} & U-10 vs. U-13 & -6.68 & 0.00 & Less vs. Middle & -4.89 & 0.00 \\
\hline & U-10 vs. U-16 & -8.1 & 0.00 & Less vs. High & -6.85 & 0.00 \\
\hline & U-16 vs. U-13 & 1.2 & 0.47 & High vs. Middle & 1.96 & 0.94 \\
\hline \multirow{3}{*}{$\begin{array}{l}\text { Keeping the } \\
\text { ball...6 }\end{array}$} & U-10 vs. U-13 & -8.6 & 0.00 & Less vs. Middle & -7.4 & 0.00 \\
\hline & U-10 vs. U-16 & -9.99 & 0.00 & Less vs. High & -9.46 & 0.00 \\
\hline & U-16 vs. U-13 & 1.39 & 1 & High vs. Middle & 2.06 & 1 \\
\hline \multirow{3}{*}{$\begin{array}{l}\text { Moving } \\
\text { forward...7 }\end{array}$} & U-10 vs. U-13 & -4.34 & 0.11 & Less vs. Middle & -3.16 & 0.24 \\
\hline & U-10 vs. U-16 & -6.52 & 0.01 & Less vs. High & -5.02 & 0.051 \\
\hline & U-16 vs. U-13 & 2.17 & 0.71 & High vs. Middle & 1.85 & 1 \\
\hline \multirow{3}{*}{ Scoring...8 } & U-10 vs. U-13 & -9.5 & 0.12 & Less vs. Middle & -5.86 & 0.46 \\
\hline & U-10 vs. U-16 & -15.31 & 0.00 & Less vs. High & -8.86 & 0.18 \\
\hline & U-16 vs. U-13 & 5.81 & 0.48 & High vs. Middle & 3 & 1 \\
\hline \multirow[t]{3}{*}{ Total TK9 } & U-10 vs. U-13 & -9.99 & 0.00 & Less vs. Middle & -5.13 & 0.00 \\
\hline & U-10 vs. U-16 & -10.31 & 0.00 & Less vs. High & -7.45 & 0.00 \\
\hline & U-16 vs. U-13 & 0.31 & 0.83 & High vs. Middle & 2.32 & 0.52 \\
\hline
\end{tabular}

Note (all tables): 'Domain declarative specific knowledge on the technical and tactical individual elements in the sport of soccer related to TP when attacking for invasion games and sports, ${ }^{2}$ on roles and positions in soccer, ${ }^{3}$ on technical-tactical individual elements in soccer, ${ }^{4}$ on technical-tactical collective elements in soccer, ${ }^{5} \mathrm{TP}$ when attacking in invasion games and sports. ${ }^{6}$ Domain procedural specific knowledge on the use of individual technical and tactical elements in situations of keeping the ball in soccer, ${ }^{7}$ moving forward to the opposite goal in soccer, ${ }^{8}$ scoring in soccer, and ${ }^{9}$ total tactical knowledge.

hoc revealed these significant differences only between $\mathrm{U}-10$ with $\mathrm{U}-13$ and $\mathrm{U}-16$ groups in total $(\mathrm{p}=0.000$, both), declarative $(p=0.000$, both), and procedural ( $p=0.002$ and $p=0.000$, respectively) tactical knowledge. In declarative knowledge, U-13 and U-16 age groups were significantly better than $\mathrm{U}-10$ age group in all the mentioned technical and tactical subscales $(\mathrm{p}=0.000$, all), but in the roles and positions in soccer subscale,
U-16 age group was just significantly better than other age groups $(\mathrm{p}=0.000$, both). In procedural knowledge, U-13 and U-16 age groups were significantly better than U-10 age group in situation of keeping the ball subscale ( $p=0.005$, both), but in the situations of moving forward to the opposite goal and scoring subscales, a significant difference was only observed between U-16 and U-10 age groups ( $\mathrm{p}=0.013, \mathrm{p}=0.009$, respectively). 


\section{Influence of experience}

Results revealed significant differences in total, declarative, and procedural tactical knowledge $\left(\mathrm{F}_{(2,463)}=13.36\right.$, Partial $\eta^{2}=0.055 ; \mathrm{F}_{(2,463)}=10.92$, Partial $\eta^{2}=0.045$ and $\mathrm{F}_{(2,463)}=8.88$, Partial $\eta^{2}=0.037 ; \mathrm{p}=0.000$ all $)$ between less, middle, and high-experienced players. Results of Bonferroni post-hoc revealed these significant differences only between less experienced with middle and high-experienced players in total $(\mathrm{p}=0.001$ and $\mathrm{p}=0.000$, respectively), declarative $(\mathrm{p}=0.003$ and $\mathrm{p}=0.000$, respectively), and procedural ( $\mathrm{p}=0.006$ and $\mathrm{p}=0.001$, respectively) tactical knowledge. In declarative knowledge, middle and high-experienced players were significantly better than less experienced ones in individual ( $p=0.007$ and $p=0.001$, respectively) and collective $(\mathrm{p}=0.004$ and $\mathrm{p}=0.002$, respectively) technical-tactical elements of soccer and tactical principles when attacking in invasion games and sports ( $\mathrm{p}=0.004$ and $\mathrm{p}=0.002$, respectively) subscales, but in the subscale of technical-tactical individual elements when attacking for invasion games and sports, highexperienced players were only significantly better than less and middle experienced ones $(p=0.001$ and $\mathrm{p}=0.009$, respectively).

Also, in the roles and positions in soccer subscale, a significant difference was only observed between high and less experienced players $(p=0.008)$. In procedural knowledge, high and middle experienced players were significantly better than less experienced ones in situation of keeping the ball subscale $(p=0.006$ and $\mathrm{p}=0.002$, respectively). No significant differences were observed in other subscales.

\section{Discussion}

The present study was conducted to investigate and compare tactical knowledge among the Iranian soccer schools' players with U-10, U-13 and U-16 age groups and different levels of experience, due to important role of tactical knowledge in decision-making and tactical performance of the invasion sports' players. According to the results, significant differences were observed in total, declarative ,and procedural tactical knowledge among U-10, U-13 and U-16 age groups as well as less, middle, and high-experienced players. There were significant differences in knowledge of individual and collective soccer tactical-technical elements, tactical principles about invasion games and the rules and positioning sub-scales of declarative tactical knowledge, and individual technical-tactical elements in situations of keeping the ball sub-scale of tactical procedural knowledge between players with various age and experience categories.

Results of evaluating declarative and procedural tactical knowledge in defensive conditions as well as on-the-ball and off-the-ball situations revealed that organization of both knowledge will be improved (McPherson \& Kernodle, 2007) along with theincrease in age, experience (Giletal., 2011), andlevel of performance (Moreno et al., 2006). In fact, this knowledge is in the form of memory structures' representations guiding encoding of critical environmental cues, as well as recalling of concepts and patterns associated with the action (French \& McPherson, 1999). Regarding explaining this organization, it has been suggested that during the game, players save the information obtained from themselves and the opponent in working memory as goal and condition concepts. They make matching between these concepts according to the amount and type of directed attention during training and experience. Beginner player keeps both of these concepts in memory. Lack of experience makes them to be isolated, then tactical knowledge would be inefficient (Anderson, 1982). In fact, existence of these concepts in the working memory and matching of them during experience and development can be one of the major reasons for the difference between declarative and procedural tactical knowledge in the experienced and less experienced players. Then, the skilled players consider deep structures and offer more appropriate and more creative solutions to problems, whereas beginners respond to an event in a superficial way (Sternberg \& Horvath, 1995). Since, knowing and doing can mutually facilitate each other, practice and experience can lead to acquisition and maintainance of player's declarative knowledge and thus, the player's ability to make alternative decisions will be developed.

Studies have indicated that tactical performance and efficiency of young soccer players are improved by the increase in age (Americo et al., 2017). This improvement is influenced by the player's sportspecific knowledge (Giacomini et al., 2011) resulting from experience (García-Ceberino et al., 2020), age (Gil et al., 2012) ,and the amount of athlete's deliberate practice on the sport field (North et al., 2011), which was also confirmed by results of the present study. In fact, the differences observed between declarative and procedural tactical knowledge and also the knowledge of individual and collective soccer tactical-technical elements among the U-10, U-13, and U-16 age groups were in agreement with the literature, as well as between the inexperienced and experienced players (Americo et al., 2017; Del Villar et al., 2004; GarcíaLópez et al., 2010; González-Víllora et al., 2010; Serra- 
Olivares et al., 2015). Better tactical knowledge of the experienced players is in agreement with deliberate practice theory suggesting that the difference between competitive and non-competitive athletes can be related to their amount of the accumulated practice (Macnamara et al., 2016). Dedicated period for practice in the current study's soccer players probably was followed by getting continuous taskcentered and targeted instructions as well as detailed feedback about the knowledge of individual and collective soccer tactical-technical elements from the their coach. Cognitive skills or sport-specific declarative and procedural knowledge (Côté et al., 2007) were promoted through this information as the basis of tactical skills (McPherson \& Kernodle, 2003). Therefore, tactical expertise, as one of high performance preconditions in group and invasion sports (Janelle \& Hillman, 2003) was the result of formation of the soccer-specific action plan and current event profiles' dynamic during competition (McPherson, 2008). This cognitive structure led to better memory representations' retrieval of tactical knowledge in problem-solving situations. Thus, our findings suggested that the more tactical problem experiences are given to young players, the better their cognitive abilities will be to solve tactical problem.

Our results showed that U-16 team as well as the experienced players was superior than the other groups in the rules and positioning sub-scale of tactical declarative knowledge and understanding of individual technical-tactical elements in situations of keeping the ball sub-scale of tactical procedural knowledge. This indicates importance of age and experience in understanding environmental concepts and interactions in group sports, which was in agreement with the studies by Americo et al. (2017), Serra-Olivares et al. (2015) and García-López et al. (2010), who found that capacity and capability of response to tactical and representational scenes of the real game were more in the experienced players than less experienced ones. Kannekens et al. (2011) also found that positioning and deciding are two tactical skills greatly contributing in predicting adult players' performance level. These changes can be attributed to the increased cognitive capacity resulting from biological development and experiences gained during practice sessions (Matias \& Greco, 2010). Indeed, although, the amount of variance in cognitive and motor performance of young soccer players might be resulted from puberty stage and changes in body size (Malina et al., 2004) but, decision-making-based parts of sport performance will be only influenced by years of regular practice. Experience obtained from different methodologies of sport-specific knowledge educations and evaluations leads the players to fast access to their working memory, improvement of tactical knowledge, and understanding the game. Therefore, the evidence confirms the influence of biological maturation and mental-physical development on football players' tactical knowledge and behavior during maturation process and sport-specific experiences. On the other hand, as the players are in stage of transferring and orienting sport-specific knowledge in young ages, they could face with different positions and functions in the games during training. These position changes lead to contextual interference in the process of memory formation according to the forgetting theory (Lee \& Magill, 1985), suggesting that every time where a person faces with a new position, he/she relatively forgets the knowledge related to the previous position by designing new action plan, leading to decline in tactical performance related to that position (Padilha et al., 2013). However, the mentioned intervention will lead to a better memory consolidation in learning process. In this regard, it is necessary to investigate the effect of contextual interference on declarative and procedural tactical knowledge in young soccer players by changing the players' positions during practice in further studies.

Increasing experience could expand environmental awareness and memory capacity of young players, providing stronger representations of off-the-ball situations, and promoting understanding of the game (Mitchell et al., 2013). In agreement with this statement, findings of the present study showed that the experienced players have more knowledge from tactical behavior in representational off-the-ball situations. Introducing Game Performance Assessment Instrument (GPAI) to assess invasion games performance for using in teaching-learning process, Oslin et al. (1998) showed that seven components of the game performance include skill execution, base, decision-making, supporting, marking, covering, and adjusting only one of them is related to on-theball movement. This suggests importance of off-theball tactical knowledge and movements for invasion games' players and this matter needs to be considered in talent identification and development process as well as specific trainings. It is believed that quality of declarative knowledge developed in the early practice of soccer has an essential role in establishment of decision-making skills (Serra-Olivares et al., 2015) and facilitates the player's procedural tactical knowledge (Williams \& Davids, 1995). Results of the present study also showed that declarative knowledge was high influenced by age and experience. These findings were 
in line with the previous research. In a study conducted by Moreira et al. (2014), U-15 players had higher declarative knowledge compared to U-14 players, and this result was considered as an outcome of more practices and experiences in older players (Costa \& Reyes, 2015). In addition, superiority of older players was quite obvious in comparing declarative knowledge in 8-12- year-old (Serra-Olivares et al. (2015), U-14 with U-16 (Moreira et al., 2014) and U-14 with U-15 (Giacomini et al., 2011) soccer players.

In this regard, the difference in quality of declarative knowledge between young and older soccer players may be considered as one of characteristics of the players' developmental stage (Teoldo et al., 2017). At 11 years of age, as the beginning of puberty, soccer players engage in more concrete tasks facilitating their understanding of general tactical principles. Therefore, their cognitive capacity to understand teamwork dynamics and competing with opponent players in soccer may be lower than older players (González-Víllora et al., 2015). But this principle can be comprehensively understood from 12 to 13 years of age, by obtaining the ability for abstract thinking in the late years of maturation (Teoldo et al., 2017). Soccer player's declarative and procedural tactical knowledge will be improved through increase in age and experience. This improvement may be attributed to changes in age-induced players' cognitive capacity as well as saved specific representation and concepts during experiences. In consistent with the previous studies (Doostdari et al., 2015; Salehi Omran et al., 2015) demonstrating that contrary to skill and attitude objectives, cognitive objectives are still taken for granted in sport education programs of the Iranian soccer schools, our results also showed that evaluation of tactical knowledge should be taken into consideration by soccer schools' coaches. In spite of the fact that there was a need for carrying out the current workin Iran's soccer schools, our study clearly had some limitations. Although, it is believed that our work could be a framework for the next studies in Iran, but herein, a questionnaire was used and the observed differences might be attributed to features and limitations related to type of questions. Clearly, it is recommended to conduct future research to hold interviews besides using the STKT to extract more knowledge through giving more time to players for thinking.

\section{Conclusions}

Findings of this study supported the idea that the experienced soccer schools' players have more organized tactical knowledge to respond to representational scenes of real game of soccer. On the other hand, tactical knowledge in soccer is acquirable and its evaluation has an important role in teachinglearning process of soccer schools. These findings add to a growing body of literature on the need for providing appropriate experiences to the young soccer players in order to develop their tactical knowledge. 


\section{REFERENCES}

Americo, H. B., Kowalski, M., Cardoso, F., Kunrath, C. A., GonzalezVillora, S., \& Teoldo, I. (2017). Difference in declarative tactical knowledge between $\mathrm{u}-11$ and $\mathrm{u}-15$ soccer players. Human Movement, 18(5), 25-30. https://doi.org/10.1515/humo-2017-0045

Anderson, J. R. (1982). Acquisition of cognitive skill. Psychological Reuiew, 89, 369-406.

Baker, J., Côté, J., \& Abernethy, B. (2003). Sport specific training, deliberate practice and the development of expertise in team ball sports. Journal of Applied Sport Psychology, 15, 12-25.

Bayer, C. (1992). The teaching of collective sports games. Barcelona: Hispano Europea.

Bjurwill, C. (1993). Read and react: the football formula. Perceptual and Motor Skills, 76, 1383-1386.

Blomqvist, M., Vanttinen, T. \& Luhtanen, P. (2005). Assessment of secondary school students' decision-making and game-play ability in soccer. Physical Education and Sport Pedagogy, 10(2), 107-119. https:// doi.org/10.1080=17408980500104992

Blomqvist, M., Luhtanen, P., \& Laakso, L. (2000). Expert-Novice Differences in Game Performance and Game Understanding of Youth Badminton Players. European Journal of Physical Education, 5(2), 208219.

Blomqvist, M., \& Vänttinen, T. (2006). Knowledge of soccer terminology in junior players. AIESEP World Congress, 258. Jyväskylä, Finland.

Borges, P. H., Guilherme, J., Rechenchosky, L., da Costa, L. C. A., \& Rinadi, W. (2017). Fundamental Tactical Principles of Soccer: a Comparison of Different Age Groups. Journal of Human Kinetics, 58, 207-214. https://doi.org/10.1515/hukin-2017-0078

Costa, M., \& Reyes, J. P. (2015). The level of declarative knowledge about tactical principles of game of football players of different categories [in Portuguese]. Revista Brasileira de Futsal e Futebol, 7(23), 111-127.

Côté, J., Baker, J., \& Abernethy, B. (2007). Practice and play in the development of sport expertise. In G. Tenenbaum \& R.C. Eklund (Eds.), Handbook of Sport Psychology (3rd ed.) (pp. 184-202). Hoboken, NJ: Wiley.

De la Vega M. R., M., \& Del Valle D. S. Maldonado R. A. F. \& Hernandez, A. M. (2008). Una nueva herramienta para la comprensión táctica del fútbol. Revista Internacional de Medicina y Ciencias de La Actividad Física y El Deporte, 8(30), 130-145.

Del Villar, F., Iglesias, D., Moreno, M. P., Fuentes, J. P., \& Cervelló, E. (2004). An investigation into procedural knowledge and decisionmaking: Spanish experienced-inexperienced basketball players differences. Journal of Human Movement Studies, 46, 407-420.

Dicks, M., Davids, K., \& Button, C. (2008). Representative task designs for the study of perception and action in sport. International Journal of Sport and Exercise Psychology, 4, 506-524.

Domínguez La Rosa, P., \& Espeso, E. G. (2002). El conocimiento metacognitivo y su influencia en el aprendizaje motor. Revista Internacional de Medicina y Ciencias de La Actividad Física y El Deporte, 2(4), 59-68.

Doostdari, S., Ganjooee, F. A. \& Soheily, B. (2015). A Survey of Football Talent Identification Problems. Sport Management (in Persian), 7(4), 621-635. https://doi.org/10.22059/JSM.2015.55971

Elferink-Gemser, M. T., Visscher, C., Richart, H., \& Lemmink, M., K. A. P. (2004). Development of the tactical skills inventory for sports. Perceptual and Motor Skills, 99, 883-895.

French, K. E., \& McPherson, S. L. (1999). Adaptations in response selection processes used during sport competition with increasing age and expertise. International Journal of Sport Psychology, 30, 173-193.

García-Ceberino, J. M., Gamero, M. G., Sebastián Feu, A., \& Ibáñez, S. J. (2020). Experience as a Determinant of Declarative and Procedural Knowledge in School Football. International Journal of Environmental Research and Publich Health, 17(1063), 1-14. https://doi.org/10.3390/ ijerph17031063

García-González, L.; Iglesias-Gallego, D.; Moreno-Domínguez, A.; GilArias, A., \& \& Del-Villar-Álvarez, F. (2011). La competición como variable precursora del conocimiento en tenis. Revista Internacional de Medicina y Ciencias de La Actividad Física y El Deporte, 11(43), 592-607.
García-López, L. M., Gutiérrez, D., González-Víllora, S., Abellán, J., \& Webb, L. (2010). Expert-novice differences in procedural knowledge in young soccer players from local to international level. Journal of Human Sport \& Exercise, 5(3), 444-452. https://doi.org/10.4100/ jhse.2010.53.14

Giacomini, D., Silva, E., \& Greco, P. (2011). Comparação do conhecimento tático declarativo de jogadores de futebol de diferentes categorias e posições. Revista Brasileira de Ciências Do Esporte, 33, 445-463.

Gil, A., Moreno, M. P., Garcia-Gonzalez, L., Moreno, A., \& Del Villar, F. (2012). Analysis of Declarative and Procedural Knowledge in Volleyball according to the Level of Practice and Players' Age. Perceptual \& Motor Skills, 115(2), 632-644. https://doi.org/10.2466/30.10.25. PMS.115.5.632-644

Gil, A., Moreno, M. P., Moreno, A., García-González, L., \& Del Villar, F. (2011). The federated practice as element of development of the knowledge: application to the formation volleyball. International Journal Sport Science, 24, 230-244.

González-Víllora, S., García-López, L. M., \& Contreras-Jordán, O. R. (2015). Decision making and skill development in youth football players. The International Journal of Medicine and Science in Physical Education and Sport, 15(59), 467-487.

González-Víllora, S., García, L., Gutiérrez, D., \& Contreras, O. R. (2010). [Tactical awareness and decision making in youth football players (12 years): a descriptive study]. Infancia y Aprendizaje, 33, 489-501.

González-Víllora, S., García López, L. M., Pastor Vicedo, J. C., \& Contreras-Jordán, O. R. (2011). Tactical knowledge and decision making in young football players (10 years old) [in Spanish]. Revista de Psicologia Del Deporte, 20(1), 79-97.

Gréhaigne, J. F. (1992). L'organisation du jeu en football [The organisation of play in soccer]. Paris: ACTIO.

Grehaigne, J. F., Richard, J. F., \& Griffin, L. (2005). Teaching and Learning Team Sports and Games. Oxon: Routledge: Taylor \& Francis Group.

Griffin, L.L., Dodds, P., Placek, J., \& Tremino, F. (2001). Middle School Students Conceptions of Soccer Their Solutions to Tactical Problems. Journal of Teaching and Physical Education, 20, 324-340. https://doi. org/10.1123/jtpe.20.4.324

Janelle, C. M., \& Hillman, C. H. (2003). Expert performance in sport: Current perspective and critical issues. In J.L. Starkes \& K.A. Ericsson (Eds.), Expert Performance in sports: Advances in research on sport expertise. Champaign, IL: Human Kinetics.

Juan, M. García-Ceberino, María, G. Gamero, Sebastián Feu, A., \& Sergio, J. I. (2020). Experience as a Determinant of Declarative and Procedural Knowledge in School Football. International Journal of Environmental Research and Publich Health, 17(1063), 3-14. https:// doi.org/10.3390/ijerph17031063

Kannekens, R., Elferink-Gemser, M. T., \& Visscher, C. (2011). Positioning and deciding: Key factors for talent development in soccer. Scandinavian Journal of Medicine and Science in Sports, 21, 846-852.

Lee, T. D., \& Magill, R. A. (1985). Can forgetting facilitate skill acquisition? In D. Goodman, R. B. Wilberg and I. M. Franks (Eds), Differing perspectives in motor learning, memory, and control (pp. 3-22). Amsterdam: Elsevier.

Macnamara, B. N., Moreau, D., \& Hambrick, D. Z. (2016). The Relationship Between Deliberate Practice and Performance in Sports: A Meta-Analysis. Prospectives on Psychological Science, 11(3), 333-350. https://doi.org/10.1177/1745691616635591

Malina, R. M., Eisenmann, J. C., Cumming, S. P., Ribeiro, B., \& Aroso, J. (2004). Maturity-associated variation in the growth and functional capacities of youth football (soccer) players 13-15 years. European Journal of Applied Physiology, 91, 555-562.

Matias, C. J., \& Greco, P. J. (2010). Cognition and action in team ball sports. Cognição e Ação, 15, 252-271.

McGee, R., \& Farrow, A. (1987). Test questions for physical education activities. Champaign: Human Kinetics.

McPherson, S. L. (2008). Tactics: using knowledge to enhance performance. In Farrow D, Baker J, MacMahon C. Developing sport expertise: 
researchers and coaches put theory into practice (pp. 155-167). London: Routledge.

McPherson, S. L., \& Kernodle, M. W. (2003a). Tactics, the neglected attribute of expertise: problem representations and performance skills in tennis. In Starkes JL, Ericsson KA. Expert performance in sports: advances in research on sport expertise (pp. 137-168). Champaign Human Kinetics.

McPherson, S. L., \& Kernodle, M. W. (2003b). Tactics, the neglected attribute to expertise: problem representations and performance skills in tennis. In J. L. Starkes \& K. A. Ericsson (Eds.), Expert performance in sports: advances in research on sport expertise (pp. 137167). Champaign, IL: Human Kinetics.

McPherson, S. L., \& Kernodle, M. W. (2007). Mapping two new points on the tennis expertise continuum: tactical skills of adult advanced beginners and entry-level professionals during competition. Journal of Sports Sciences, 25, 945-959.

McPherson, S. L., \& Thomas, J. R. (1989). Relation of knowledge and performance in boys' tennis: age and expertise. Journal of Experimental Child Psychology, 48(2), 190-211. https://doi.org/10.1016/00220965(89)90002-7

Mitchell, S. A. Oslin, J. A. \& Griffin, L. L. (2013). Teaching sport concepts and skills : a tactical games approach for ages 7 to 18. Champaign, IL: Human Kinetics.

Moreira, P. D., Soares, V. O. V., Praça, G. M., Matias, C. J. A. S., \& Greco, P. J. (2014). Declarative tactical knowledge in soccer players [in Portuguese]. Kinesis, 32(2), 87-99. https://doi.org/105902/0102830814693

Moreno, A., Moreno, M. P., García-González, L., Iglesias, D., \& Del Villar, F. (2006). Relación entre conocimiento procedimental, experiencia y rendimiento: un estudio en voleibol. Motricidad: European Journal of Human Movement, 17, 15-24.

Moreno, M. P., Moreno, A., Ureña, A., Iglesias, D., \& Del Villar, F. (2008). Application of mentoring through reflection in female setters of the Spanish national volleyball team: a case study. International Journal of Sport Psychology, 39, 59-76.

North, J. S., Ward, P., Ericsson, A., \& Williams, A. M. (2011). Mechanisms underlying skilled anticipation and recognition in a dynamic and temporally constrained domain. MEMORY, 19, 155-168.

Oslin, J. L., Mitchell, S. A., \& Griffin, L. L. (1998). The Game Performance Assessment Instrument (GPAI): development and preliminary validation. Journal of Teaching in Physical Education, 17, 231-243.

Padilha, M. B., Moraes, J. C., \& Teoldo, I. T. (2013). O estatuto posicional pode influenciar o desempenho tático entre jogadores da categoria Sub-13? Revista Brasileira de Ciência e Movimento, 21, 73-79.
Salehi Omran, E., Javadipour, M. \& Mohammadizad, S. (2015). The amount of educational goals achievement in physical education course in elementary schools of Mazandaran province. Management and Sport Development: A Biannual Journal, 2(7), 124-135.

Serra-Olivares, J., \& García-López, L. M. (2016). Design and Validation of the Soccer Tactical Knowledge Test (STKT). Revista Internacional de Medicina y Ciencias de La Actividad Física y El Deporte, 16(62), 521536. https://doi.org/10.15366/rimcafd2016.63.008

Serra-Olivares, J., García-López, L. M., \& Calderón, A. (2015). Tactica domain-specific knowledge in young soccer players aged 8-12 [in Spanish]. Apunts Educación Física y Deportes, 122(4), 36-43. https:// doi.org/10.5672/apunts.2014-0983

Serra-Olivares, J., García-López, L. M., Calderón, A., \& Cuevas Campos, R. (2015). Relationship between young soccer players' tactical knowledge and age, experience and level of expertise [in Spanish]. Cuadernos de Psicología Del Deporte, 15(3), 105-112. https://doi. org/10.4321/S1578-84232015000300010

Starkes, J. L., \& Ericsson, K. A. (2003). Expert Performance in Sports: Advances in Research on Sport Expertise. Champaign, IL: Human Kinetics.

Sternberg, R. J., \& Horvath, J. A. (1995). A prototype view of expert teaching. Educational Research, 24, 9-17. https://doi.org/10.3102/ 0013189X024006009

Suppiah, H. T., Low, C. Y. \& Chia, M. (2015). Detecting and developing youth athlete potential: different strokes for different folks are warranted. British Journal of Sports Medicine, 49(13), 878-882. https://doi.org/10.1136/bjsports-2015-094648

Teoldo, I., Guilherme, J., \& Garganta, J. (2017). Training football for smart playing: on tactical performance of teams and players. Curitiba: Appris.

Vazinitaher, A., Shahbazi, M. \& Bagherzadeh, F. (2011). Multivariate approach in talent identification of soccer players under 16 years old. Journal of Development and Motor Learning, 3(11), 103-128.

Webb, P. \& Pearson, P. (2008). An Integrated Approach to Teaching Games for Understanding (TGfU). 1st Asia Pacific Sport in Education Conference. Adelaide.

Williams, A. M., Ward, P., Bell-Walker, J., \& Ford, P. R. (2012). Perceptualcognitive expertise, practice history profiles and recall performance in soccer. Brit J Psychol, 103(3), 393-411. https://doi.org/10.1111/ j.2044-8295.2011.02081.x.

Williams, M., \& Davids, K. (1995). Declarative knowledge in sport: a byproduct of experience or a characteristic of expertise? Journal of Sport and Exercise Psychology, 17(3), 259-275. https://doi.org/10.1123/ jsep.17.3.259 